\title{
Pseudo-Nitzschia pseudodelicatissima Isolated From Hurun Bay: Salinity Tolerance and Domoic Acid Content
}

\author{
Pseudo-Nitzschia pseudodelicatissima Hasil Isolasi Dari Teluk Hurun: Toleransi \\ Terhadap Salinitas dan Kandungan Asam Domoat
}

\author{
Lily M.G. Panggabean \\ Research Centre for Oceanography-LIPI \\ Jl, Pasir Putih, 1 Ancol Timur, Jakarta.Email: mglilyp@yahoo.com
}

\begin{abstract}
Pseudo-nitzschia pseudodelicatissima dari sampel perairan Teluk Hurun, Lampung berhasil diisolasi dan dikultur dalam medium F/2 dengan penyinaran 2500 luks 12 jam per hari pada suhu $24-25^{\circ} \mathrm{C}$. Perlakuan salinitas menunjukkan bahwa $P$. pseudodelicatissima tidak toleran terhadap salinitas kurang dari 15 PSU dan sangat toleran terhadap salinitas yang tinggi hingga mencapai 45 PSU (Pressure Salinity Unit). Salinitas optimum untuk pertumbuhan P.pseudodelicatissima yaitu pada 30 dan 35 PSU. Analisis ekstrak $P$. pseudodelicatissima, 9 hari sesudah inokulasi, menggunakan HPLC-UV tidak menunjukkan adanya kandungan asam domoat.
\end{abstract}

Kata kunci: Pseudo-nitzschia pseudodelicatissima, toleransi salinitas, asam domoat, teluk Hurun

Diterima: 05 Agustus 2006, disetujui: 01 Februari 2007

\section{Introduction}

The diatoms species Pseudo-nitzschia is a cosmopolitan genus in coastal waters around the world. Several Pseudo-nitzschia species are important because they produce domoic acid (DA), the cause of the outbreaks of amnesic shellfish poisoning (ASP). ASP toxin (domoic acid) has given a great fright to the fisheries since the first ASP outbreak in Prince Edwards Islands, Canada (1987) was traced to be produceed by the bloom of Pseudo-nitzschia multiseries (Hasle) which was formerly identified as $P$. pungens $\mathrm{f}$. multiseries (Bates et al., 1989) Since then nine more Pseudonitzschia species mostly from temperate waters were reported to produce DA (Bates, 2000, Lundholm, et al., 2003), i.e. P. australis; P. caliantha, $P$. delicatissima; $P$. fraudulenta; $P$. multiseriata;. $\quad P$. pseudodelicatissima, Lundholm, $P$. pungens; $P$. seriata and $P$. turgidula. There was little information on the toxicity of Pseudo nitzschia from tropical areas such as Philippines (Bajarias et al., 2005), Vietnam (Kotaki et al., 2000) and Indonesia (this paper).

Pseudo-nitzschia live in abundance in coastal waters of a wide range of salinities. Therefore salinity is considered to be one of the important abiotic factor affecting growth. Here the effect of salinity on the growth of Pseudonitzschia pseudodelicatissima isolated from Hurun Bay, Lampung was examined.

Bates et al., (1989) atau 89?? reported that Pseudo-nitzschia species from different locations do not always content domoic acid, such as $P$. pungens of the Pacific coast was found toxic in one location in New Zealand, but mostly nontoxic in Atlantic coast of Canada, Atlantic coast of USA, the Gulf of Mexico, Monterey Bay, Europe and New Zealand. Further results of laboratory studies indicated that level of DA production varies depending on Pseudo-nitzschia spp. and location. Therefore the isolate was analyzed for the confirmation wether Pseudo-nitzschia 
pseudodelicatissima found in Hurun Bay, Lampung Indonesia produces DA or not.

\section{Materials and Methods}

\section{Isolation and Culture}

Phytoplankton samples were collected from mangrove estuary at Hurun Bay, Lampung by vertically towing planktonnet at a depth of only $2 \mathrm{~m}$. Two kinds of Pseudonitzschia (one belongs to seriata and one was delicatissima group) were isolated by capillary method and inoculated singly into $1 \mathrm{~mL} \mathrm{~F} / 10$ (Guilard, 1983). Isolates were then transferred to $40 \mathrm{~mL} \mathrm{~F} / 2$ medium in erlenmeyer flask and maintained at $24-25^{\circ} \mathrm{C}$ under 3000 lux at 12 hrs/day illumination. Of the two isolates, one smaller (delicatissima group) grew well, but the larger group (seriata) failed to grow. The remaining culture was acclimatized to different salinities, i.e. 5, 10, 15, 20, 25, 30, 35, 40 and 45 PSU. They were grown to reach early stationary phase and used as inoculum. Cultures acclimatized to 5 and10 PSU failed to grow. Consequently, treatments for salinities in three replicates started only from 15 to 45 PSU.

\section{AnalysisforDA and Species Identification}

Aliquots or $10 \mathrm{~mL}$ samples at day 9 were sampled from the batch at $30 \mathrm{PSU}$, added $5 \mathrm{~mL}$ methanol and sent to National Centre for Fishery Quality Control and Processing Technology Development, Ministry of Marine and Fisheries Affair for domoic acid UVHPLC analysis according to Quilliams (2003). Remaining cells of inoculum were fixed in lugol solution then rinsed and treated with $\mathrm{HCl}$ $10 \%$ and $\mathrm{H} 2 \mathrm{SO} 430 \%$, boiled about one minute and rinse again, then mounted using MGK solution. Species identification of the "clean' diatom was conducted by observing morphological characteristics using light microscope. References for species identification were Fryxel and Hasle (2003) and Hasle and Sylvertsen (1997).

\section{Results and Discussions}

\section{Species Description}

Cells elongate, stepped chain united by very short overlap of valve ends. In active growth condition, chains were loosed to single cells. Valve slightly lanceolate with slightly rounded ends. Central interspace present. Apical axis 38-60 $\mu \mathrm{m}$. Transapical axis 2.2-2.4 $\mu \mathrm{m}$. Striae of the 'clean cells' of the diatom were difficult to observe with light microscope (Figure 1). Based on the shape and size only, the species was similar to Pseudo-nitzschia delicatissima according to Fryxel and Hasle (2003). The strain was then brought to Japan by Dr. Kotaki for further SEM observation, and identified as Pseudo-nitzschia pseudodelicatissima. Further description will be consulted later with diatom taxonomist.

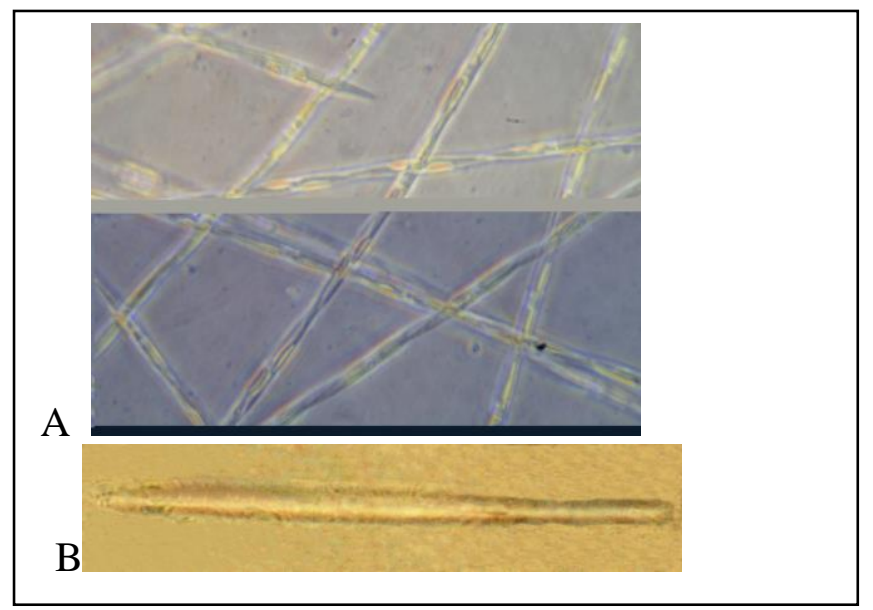

Figure 1. Pseudo-nitzschia pseudodelicatissima: A) chain cells; B) single cell appearance after removal of cytoplasma by acid cleaning 


\section{Effects of Salinities}

P. pseudodelicatissima responded by different growth patterns at different salinities. Average growth rates were $0.77 ; 0.86,0.97$, $2.2 ; 1.46$ and 0.92 cells/day respectively for $P$. pseudodelicatissima grown at 15, 20, 25, 30, 35, 40, and 45 PSU (Table 1.) Analysis of variance (ANOVA) followed by Duncan test for growth rates indicated that $P$. pseudodelicatissima grown at 30 PSU was significantly different $(\mathrm{P}<0.05)$ with that of 15 , $20,25,40,45$ PSU but no significant differences with that of 35 PSU (Figure 2). ANOVA for cell density at day 7 indicated the cell density of $P$. pseudodelicatissima grown at 30 PSU was significantly different $(\mathrm{P}<0.05)$ with that of $15,20,40,45$ PSU but no significant differences with that of 25 and 35 PSU.

Results of salinitiy experiment indicated that this strain can tolerate a salinity range of 15 to 45 PSU or more, but they grow optimally at a narrower salinity range of 30 to 35 PSU. Growth test for $P$. pseudodelicatissima at lower salinity (5 and 10 PSU) has failed to grow when acclimatized. It was indicated that $P$. pseudodelicatissima was not tolerant to salinities lower than 15 PSU. This result was similar to the study of Thessen et al. (2005) who also reported the lowest salinity tolerance for the growth of three strains of $P$. pseudodelicatissima was 15 PSU. On the other hand, $P$. pseudodelicatissima are halotolerant species. In accordance with Thessen et al., (2005), P. pseudodelicatissima was able to grow at higher salinities up to 45 PSU or maybe more. This result also agrees with the natural condition in Louisiana coastal waters observed by Thessen et al. (2005), who showed that Pseudonitzschia spp. were present over a salinity range of 1 to $>35 \mathrm{PSU}$, but they occurred more frequently at higher (between 22 to $28 \mathrm{PSU}$ ) rather than lower salinities.

Table 1. Growth rates (cells/day) of $P$. pseudodelicatissima at 15, 20, 25, 30, 35, 40, and $45 \mathrm{PSU}^{\circ} 23^{\circ} \mathrm{C}$ under 3000 lux at $12 \mathrm{hrs} /$ day illumination

\begin{tabular}{cccccccc}
\hline \hline \multirow{2}{*}{ Replicates } & \multicolumn{7}{c}{ Salinities (PSU) } \\
\cline { 2 - 9 } & $\mathbf{1 5}$ & $\mathbf{2 0}$ & $\mathbf{2 5}$ & $\mathbf{3 0}$ & $\mathbf{3 5}$ & $\mathbf{4 0}$ & $\mathbf{4 5}$ \\
\hline \hline A & 1.15 & 0.88 & 0.68 & 2.11 & 1.33 & 1.40 & 0.88 \\
B & 0.55 & 0.78 & 1.03 & 2.15 & 1.49 & 1.40 & 0.91 \\
C & 0.61 & 0.93 & 1.21 & 2.34 & 1.57 & 1.06 & 0.99 \\
\hline \hline Average & 0.77 & 0.86 & 0.97 & $2.20 * *$ & $1.46^{*}$ & 1.29 & 0.93 \\
SD & 0.33 & 0.08 & 0.27 & 0.12 & 0.12 & 0.20 & 0.06 \\
\hline \hline
\end{tabular}

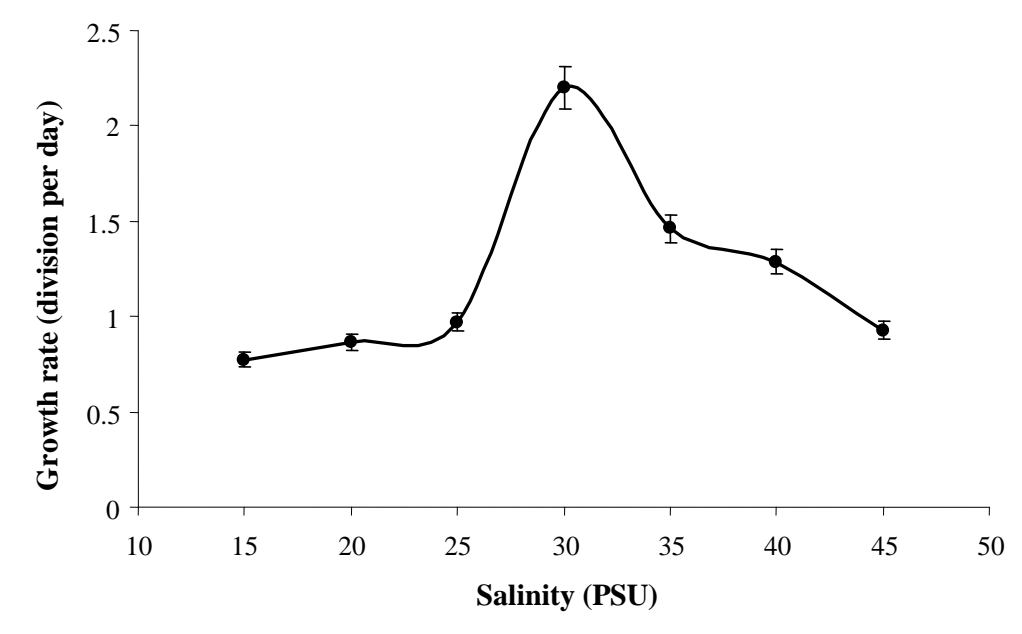

Figure 2. Growth rate of Pseudo-nitzschia pseudodelicatissima isolate from Lampung Bay cultured at different salinities under $23^{\circ} \mathrm{C}$ room temperature and $3000 \mathrm{lux}$, at $12 \mathrm{hrs} /$ day illummination 
Comparing to other Pseudonitzschia spp., $P$. pseudodelicatissima was not tolerant to low salinities. According to Thessen et al. (2005), tolerance of low salinities decreased from $P$. delicatissima to $P$. multiseries to $P$. pseudodelicatissima. The limit of lower salinity for $P$. delicatissima is 6.25 PSU; $P$. multiseries is $10 \mathrm{PSU}$ and $P$. pseudodelicatissima is 15 PSU respectively.

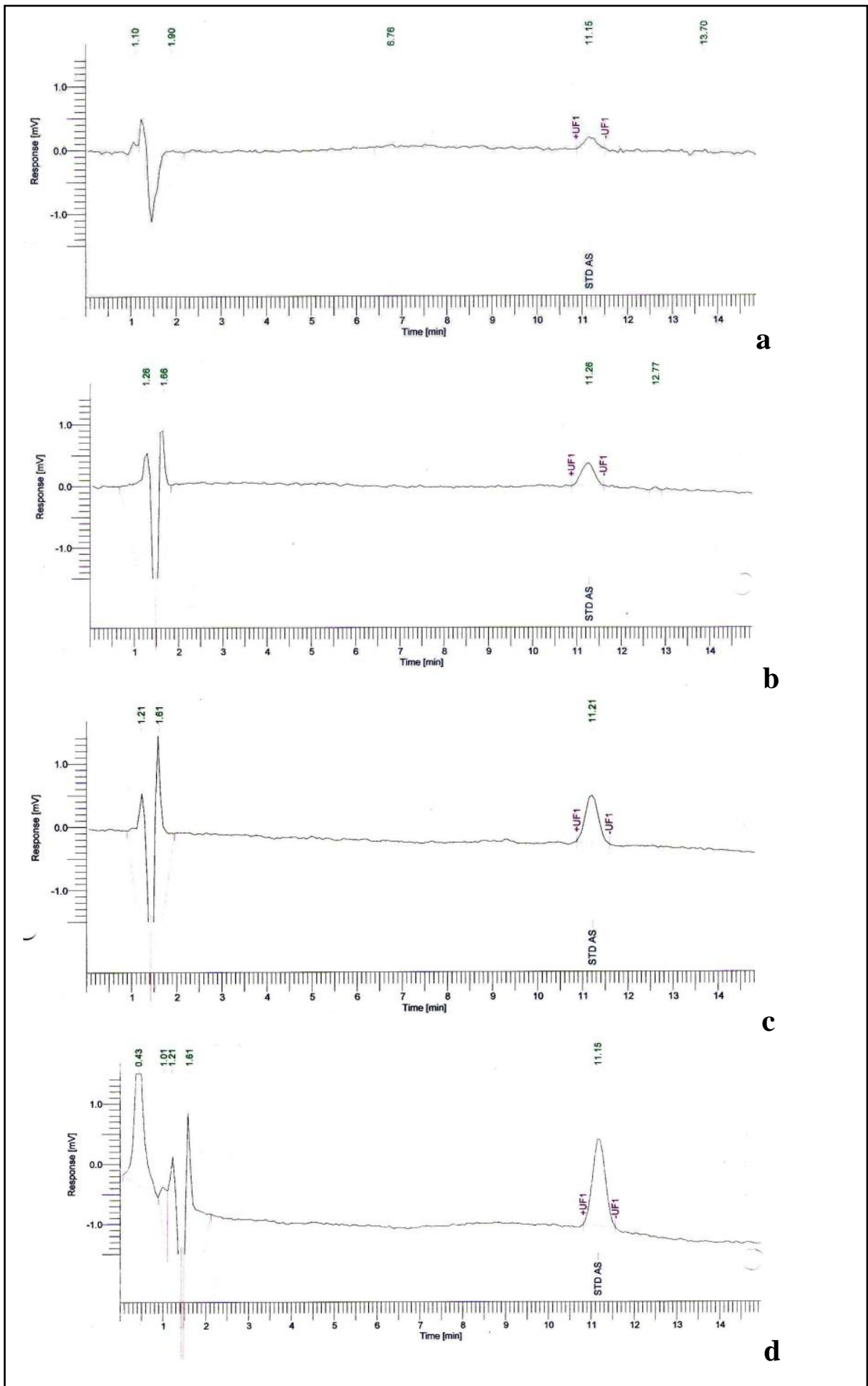

Figure 3. HPLC-UV chromatogram Domoic acid standard: a) 0,1 ppm; b) 0,2 ppm; c) $0,4 \mathrm{ppm}$;) $0,8 \mathrm{ppm}$

Biota Vol. 12 (1), Februari 2007 


\section{Domoic acid analysis}

Figure 5 shows HPLC-UV chromatograms of the extract of $P$. pseudodelicatissima culture at day 9 after inoculation. In contrast with chromatogram of standard for ASP (0.1-0.8 ppm domoic acid) and blank samples (Figure 3, 4), the extract of $P$. pseudodelicatissima showed no peak at all indicating that the strain was not producing domoic acid. However this result must be considered preliminary. Chromatogram of the 9 day culture was not reliable. It has been reported so far (Kotaki, 2002) that levels of DA production were varied among Pseudo-nitzschia spp. High level of DA content was observed in Pseudo-nitzschia multiseries, (Hasle) P. australis Frenguelli and $P$. seriata (Cleve) H. Peragallo, while $P$. pseudodelicatissima and four other Pseudo-nitzschia spp. were included in the diatoms producing low level of DA.
According to Kotaki (Pers. Communication, 2005), the sampling time (day 9 after inoculation) for domoic acid analysis was been early. At this time, at this stage at domoic acid might have not produced yet or just started to be produced by $P$. pseudodelicatissima. The inexperienced author has sampled randomly and assumed that at any stationary phase the diatom cells were already producing domoic acid. This assumption was based on the study of domoic acid production for Nitzschia sp. which was observed by Kotaki et al., (2000). Kotaki suggested (Pers. Communication, 2005) that appropriate sampling time for Pseudo-nitzschia should be at the late stationary phase when cells of Pseudo-nitzschia ceased their division and domoic acid per cell became maximum. Low content of domoic acid in the culture of Pseudonitzschia might probably be detected at later stationary phase at least after 21 days culturing.

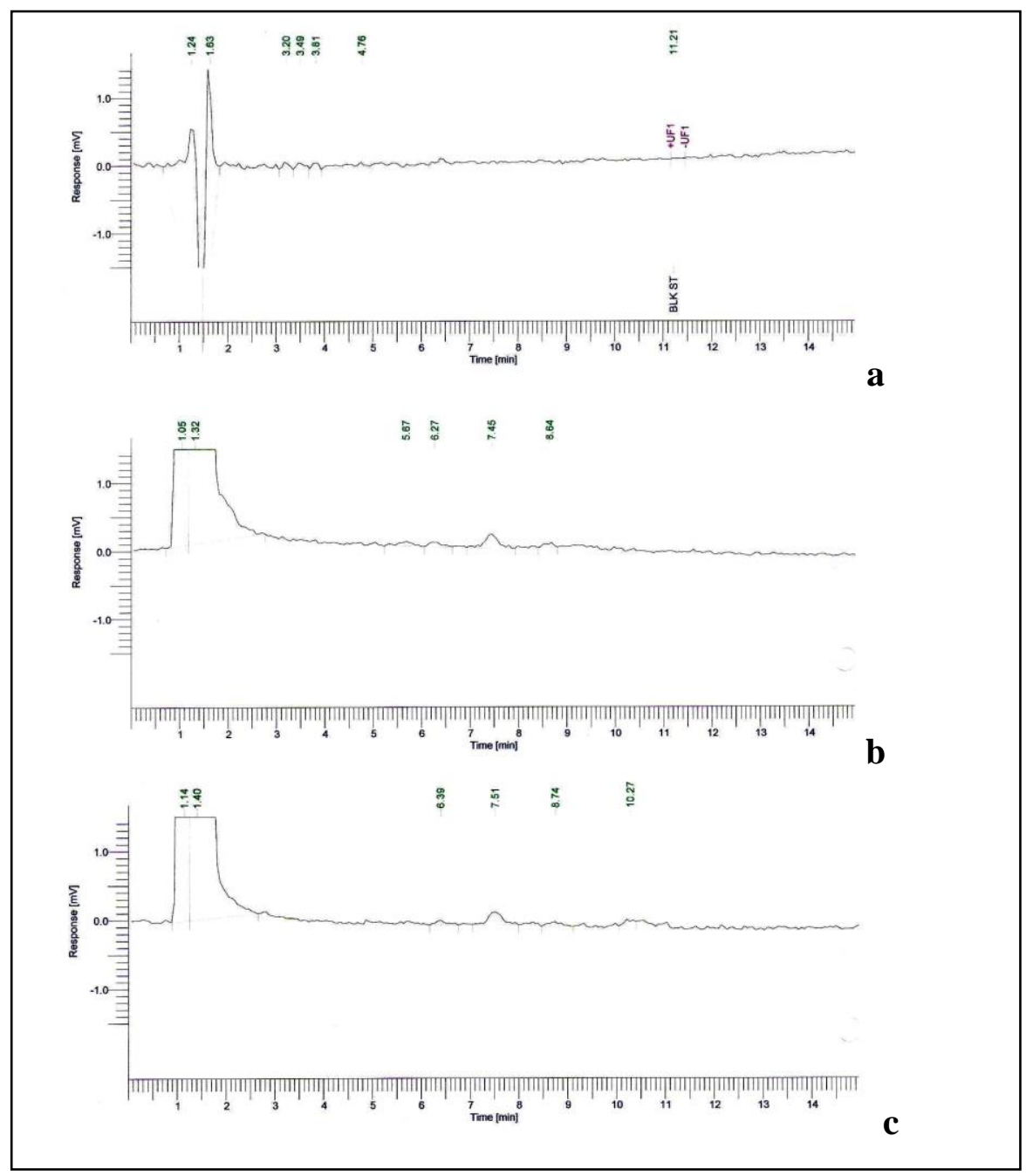

Figure 4. HPLC-UV chromatogram of the a) blank, b) blank reagen for domoic Acid 01 and c) 02 


\section{Conclusions}

The diatom strain Pseudo-nitzschia pseudodelicatissima from Lampung Bay was tolerant to higher (15 to 45 PSU or more) rather than lower salinities (no growth under 10 PSU or below) but they grow optimally at 30 to 35 PSU. The halotolerant character of this species agreed with other studies (Thessen et al., 2005). The strain was considered non producing domoic acid, however, result of this study must be considered preliminary. Non toxigenic character of this strain should be reconfirmed by future works. Isolate was identified as Pseudo-nitzschia pseudodelicatissima. Proper description of the
Pseudo-nitzschia species will be published elsewhere.

\section{Acknowledgement}

I would like to thank Kotaki Sensei for his advice on the future works and providing the access to proper identification of the diatom. Thanks also to Serli Sapulete for isolation and culturing Pseudo-nitzschia spp., Trimaningsih for biomass data, Mufidah Fitriati for HPLC domoic acid analysis, Diah Radini for data entry, Muawanah cs. for loaning us sampling boat in Hurun Bay. Support of this research was provided by Research Centre for Oceanography, Indonesian Institute for Science (LIPI).

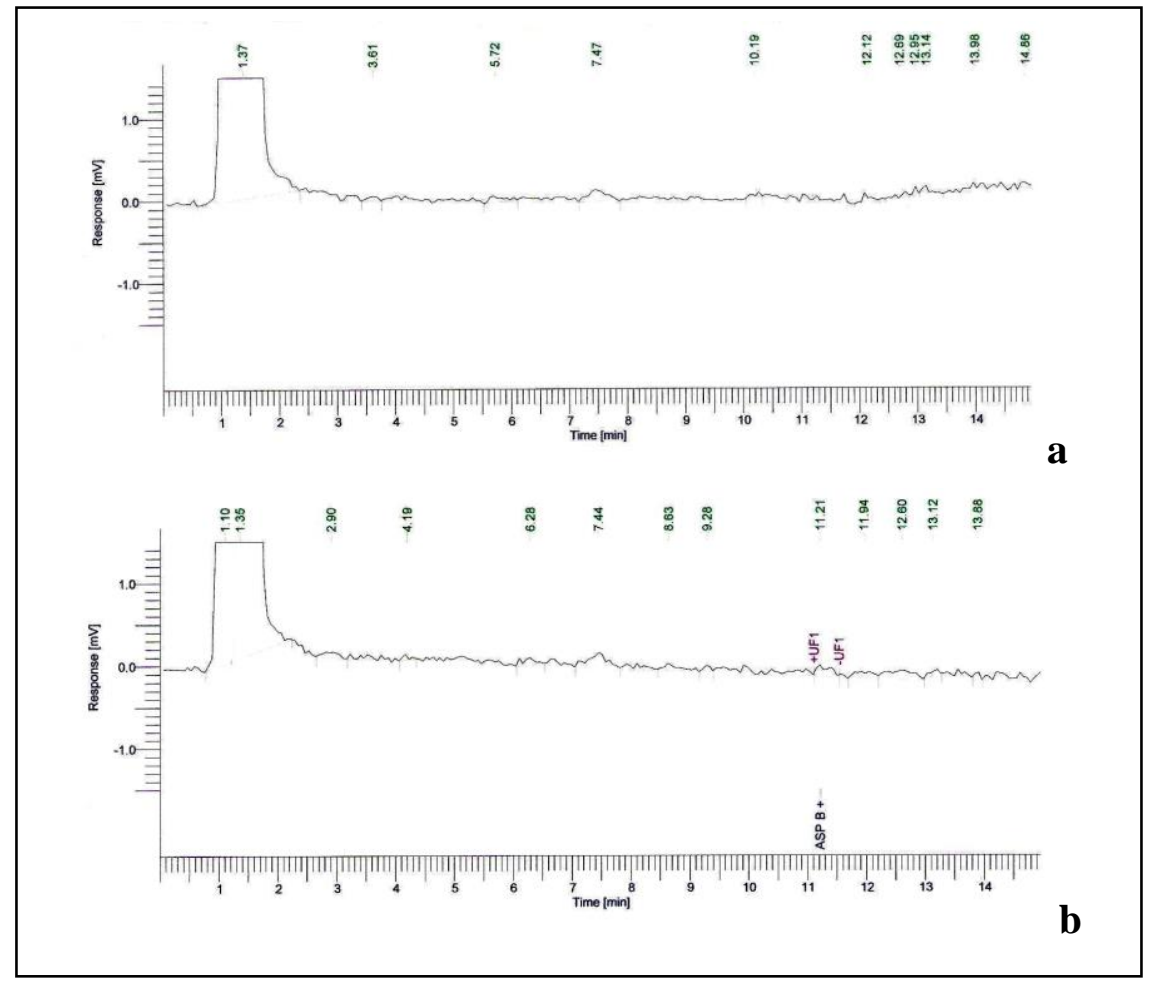

Figure 5. HPLC-UV chromatogram of the a) sample A; b) sample B added by 0.8 ppm domoic acid

\section{References}

Bajarias, F.A., Kotaki, Y., Relox, J.R., Romero, M.L.J., Furio, E.F. Lundholm, N., Koike, K., Fukuyo, F. and Kodama, M. 2006. Screening of diatoms producing domoic acid and its derivatives in the Philippines. Coastal Mar. Scie. 30(1):121-129.

Biota Vol. 12 (1), Februari 2007
Bates. S.S., Bird, C.J., de Freitas, A.S.W., Foxall, R., Gilgan, M., Hanic, L.A., McCulloch, G.R., Odense, P., Pocklington, R., Quilliam, M.A., Sim, P.G., Smith, J.C., SubbaRao, D.V., Todd, E.C.D., Walter, J.A. and Wright, J.L.C. 1989. Penneate diatom Nitzschia pungens as the primary source of domoic acid, a toxin in shellfish from eastern Prince Edward Island, Canada. Can. J. Fish. Aquat. Sci. 46:12031215. 
Bates, S.S. 2000. Domoic-acid-producing diatoms: another genus added. J. Phycol. 36:978-985

Fryxell, G.A. and Hasle, G.R. 2003. Taxonomy of harmful diatoms. In Manual on Harmful Marine Microalgae, Monographs on oceanographic methodology 11. Hallegraeff, G.M., Anderson and D.M., Cembella, A.D. (eds), pp. 465-509, Unesco, Paris

Guillard, R.R.L. 1983. Culture of phytoplankton for feeding marine invertebrates. In: Culture of Marine Invertebrate Animals. Selected Readings (Berg Jr., C.J. ed.) Hutchinson Ross Pub. Co. Stoudsberg, PA. USA.:108-132.

Hasle, G.R. and Syvertsen, E.E. 1997. Marine Diatoms. In Identifying Marine Phytoplankton. Tomas, C. (ed.), pp.5-385, Academic Press

Kotaki, Y. 2002. Production of domoic acid by diverse species of pennate diatoms. Fisheries science suppl. I. 68:525-528
Kotaki, Y., Koike, K., Yoshida, M., Thuoc, C.V., Huyen, N.T.M., Hoi, N.C., Fukuyo, Y. and Kodama, M. 2000. Domoic acid production in Nitzschia sp. (Bacillariophyceae) isolated from a shrimp-culture pond in Do Son, Vietnam. $J$. Phycol. 36: 1057-1060.

Lundholm, N., Moestrup, O., Hasle, G.R. and HoefEmden, K. 2003. A study of the $P$. Pseudodellicatissimalcuspidata complex (Bacillariophyceae); what is Pseudo-nitzschia pseudidelicatissima? J. Phycol. 39:797-813.

Quilliam, M.A. 2003. Chemical methods for domoic acid, the amnesic shellfish poisoning (ASP) toxin. In Manual on Harmful Marine Microalgae, Monographs on oceanographic methodology 11. Hallegraeff, G.M., Anderson and D.M., Cembella, A.D. (eds), pp. 247-278, Unesco, Paris

Thessen, A.E., Dortch, Q., Parson, M.L. and Morrison, W. 2005. Effect of salinity on Pseudonitzschia species (Baxillariophyceas) growth and distribution. J. Phycol. 41:21-29. 